This is an electronic reprint of the original article. This reprint may differ from the original in pagination and typographic detail.

Author(s): Jääskelä, Päivikki; Nykänen, Seija; Tynjälä, Päivi

Title: $\quad$ Models for the development of generic skills in Finnish higher education

Year: $\quad 2018$

Version:

Please cite the original version:

Jääskelä, P., Nykänen, S., \& Tynjälä, P. (2018). Models for the development of generic skills in Finnish higher education. Journal of Further and Higher Education, 42(1), 130-142. https://doi.org/10.1080/0309877X.2016.1206858

All material supplied via JYX is protected by copyright and other intellectual property rights, and duplication or sale of all or part of any of the repository collections is not permitted, except that material may be duplicated by you for your research use or educational purposes in electronic or print form. You must obtain permission for any other use. Electronic or print copies may not be offered, whether for sale or otherwise to anyone who is not an authorised user. 


\title{
Models for the development of generic skills in higher education
}

\begin{abstract}
This article examines how universities and other higher education institutes have responded to the challenges posed by rapid changes in the world of work and society, particularly with reference to the development of generic skills. The data were collected by means of individual and group interviews at three Finnish higher education institutes, including two universities and one university of applied sciences. The interviews involved 63 persons in charge of management, development, and teaching at these institutes. As a result of the qualitative data analysis, we distinguished four models to represent the development of generic skills, which we named (1) Specialist Model, (2) Science-Based Renewal Model, (3) Project-Based Integrative Model, and (4) Model of Networked Culture. These models serve as analytical tools that help higher education institutes to examine their existing practices and to develop new ones.
\end{abstract}

Keywords: generic skills, educational development, models, research universities, universities of applied sciences, university teaching

\section{Introduction}

\section{Generic competencies as a challenge to higher education}

Rapid changes in the labour market as well as globalisation and the development of the information society have made the operational environment of higher education more complex. The policies of the European Union have stressed sustainable economic growth, employment, creation of better jobs, and promotion of competence and innovation (Lisbon Strategy 2001-2010). These aims are pursued, for instance, in the integrated European Higher Education Area through intergovernmental collaboration known as the Bologna Process (see http://www.ond.vlaanderen.be/hogeronderwijs/bologna/documents/). At the same time, universities are debating the reconciliation between the Humboldtian ideal of the university as a place of civilization and the newer functions of higher education in society (e.g., Santiago, Carvalho, and Relva 2008).

As a consequence of rapid societal changes, more attention has recently been paid to the competencies that educational systems produce. An example of this is the DeSeCo project (Definition and Selection of Competencies) launched by the OECD at the turn of the millennium (Rychen and Salganik 2003), which defined the following central competence areas for all citizens: (1) interaction in various groups; (2) autonomous action; and (3) interactive use of different tools including (a) verbal, symbolic, and textual devices; (b) use of knowledge and information; and (c) interactive use of technology. In the European Union, the European Qualifications Framework (European Qualifications Framework 2008) defines the skills, knowledge, and competencies to be developed at different levels of education. There also exist similar trends specifically with respect to higher education. For example, 
the development of the European Higher Education Area has raised discussions about educational outcomes and their definitions. One example of these is the set of the so-called Dublin descriptors for the competencies attained at different levels of higher education qualifications. These descriptions cover the following competence areas: (1) knowledge and understanding, (2) applying of knowledge and understanding, (3) making judgements, (4) communication, and (5) lifelong learning skills (Framework of Qualifications for the European Higher Education Area 2005).

According to several surveys, higher education graduates have found that their education has not provided them with sufficient skills and competencies for work (e.g., Crebert et al. 2004; Murtonen et al. 2008; Stenström 2006; Teichler 2007; Tynjälä et al. 2006). In many countries, national education policies have highlighted the relationship between education and work and the importance of the scaffolding of students' generic competencies as the main developmental targets. For example, in Finland, the national development plan for research and education for 2007-2012 called for increasing interaction between higher education institutes and the workplace, companies, and regions. The central idea of the interaction was that the curricula could both manifest and anticipate future competence demands at work, and the students could better prepare themselves for prospective professional duties (Education and Research 2007-2012, 38). The current plan for 2011-2016 continues the education policy of previous years by guiding higher education institutions to intensify contacts with working life and to offer students up-to-date knowledge and career guidance with the aim of better employment prospects (Education and Research 2011-2016, 17).

Another indication of the interest in higher education outcomes is the international feasibility study AHELO (Assessment of Higher Education Learning Outcomes) conducted by the OECD. The purpose of this study was to investigate whether it is possible to assess, across different countries and cultures, the competencies provided by higher education. This project examined learning outcomes in two different fields of science, economics, and technology. Generic skills defined as critical thinking, analytical reasoning, problem-solving skills, and written communication were included in this study (OECD 2013).

This article seeks to analyse the problematic issue of generic skills in higher education institutes and to outline different models by which higher education institutes are responding to the challenge pertaining to the development of generic skills for work. Below, we first look at previous research literature on generic skills and then present the methods and results of our study. 


\section{Generic skills as a concept and research target}

General work-related skills provided by education are referred to by many different concepts, such as transferable skills, generic skills, generic attributes, generic competences, generic capabilities, or key skills (e.g., Jones 2009a, 2009b; Kember, Leung, and Ma 2007; Barrie 2007). These terms refer to competencies that education should provide regardless of the specific field and that can be used in a variety of tasks. For instance, different critical and scientific thinking skills, social skills, communication skills, problem-solving skills, or project work skills are often mentioned as examples of such competencies. The term 'transferable skills' also refers to the assumption that these skills could be transferred from one field or context to another. This view has been criticised, however, in that generic skills are also largely bound to their context and field (see, e.g., Bereiter and Scardamalia 2003, 55; Dunne, Benett, and Carr 2000).

Many authors have attempted to analyse and define what types of skills and knowledge are included in generic skills (e.g., Gilbert et al. 2004; Kallioinen 2010). On the other hand, there are critical views concerning the concept of generic skills and its usefulness in education (e.g., Barnett 2004). These comments underline that, in our rapidly changing world, it is impossible to know exactly what type of competence will be needed in the future. Therefore, instead of concentrating on specific competencies, attention should be paid to creating favourable conditions for lifelong learning; providing support for caring, persistent, critical, and ethical human character; and constructing appropriate learning environments for collaborative innovation.

At present, pedagogical development is increasingly aiming at the development of generic skills. Different pedagogical solutions have been developed to respond to the challenge of the development of generic skills in a better manner than traditional ways of instruction (e.g., Ballantine and McCourt Larres 2007; Tynjälä et al. 2009). Kember, Leung and $\mathrm{Ma}$ (2007) identified the following characteristics pertinent to learning environments that facilitate the development of generic skills: interactive and activating teaching that strives for the understanding of the main concepts, collaborative learning, feedback and support, and versatile evaluation methods. Virtanen and Tynjälä's (2013) findings are highly similar but add a few characteristics to the list: the connection between theory and practice, contacts to the world of work, and dealing with authentic problems. In light of several studies, the model of integrative pedagogy, in which teaching integrates the basic components of expertise (i.e., theoretical knowledge, practical knowledge, sociocultural knowledge, and 
self-regulative knowledge), seems a quite promising pedagogic solution (Tynjälä, Häkkinen and Hämäläinen 2014; Heikkinen, Tynjälä and Kiviniemi 2011; Virtanen, Tynjälä, and Eteläpelto 2014).

Research interest in the connection between education and work, and also in generic skills, stemmed from vocational education research. At the turn of the millennium, the British scholars Guile and Griffiths (2001; see also Griffiths and Guile 2003) analysed various European models of organising work experience in vocational education and training. They identified five different models: (1) Traditional Model, in which students are simply sent to the workplace; (2) Experiential Model, which seeks to increase students' awareness of their competencies; (3) Generic Model highlighting the acquisition and evaluation of generic skills; (4) Work Process Model emphasising the development of holistic systems thinking; and (5) Connective Model focusing on establishing a pedagogical link between school-based learning and work practice so that education and the workplace can jointly create learning environments. These models differ from each other, for instance, in how they view the purpose of work practice. In the Traditional Model, the purpose is mostly to provide an initial touch of work whereas in the Connective Model, the aim is to prepare students for reflective and polycontextual professionalism.

\section{Research task, data, and methods}

The purpose of the present study was to analyse and describe how Finnish higher education has responded to the challenge of the development of generic skills. The following research question was addressed:

What type of general models can be identified in higher education with regard to the development of generic skills?

\section{Data}

Data were collected from 63 informants in 13 individual and 9 focus group interviews at three Finnish higher education institutes. These three institutions can be seen to adequately represent the Finnish higher education system because the differences between the individual institutions are not so large, unlike some other Western countries in which elite universities differ greatly from average ones. Small differences stem from the fact that the basic values in developing the Finnish education system are rooted in the welfare state agenda and equal educational opportunities to all citizens regardless of socioeconomic status or geographical 
location (see, Välimaa 2012). The biggest difference between these institutes is observed for the traditional universities and the universities of applied sciences. While the former represent traditional Humboldtian ideas of research-based education, the latter represent a new higher education sector offering work-related education in response to labour market needs. The higher education system comprises 14 traditional universities and 25 universities of applied sciences.

The interviewees were from one large university, one mid-sized university, and one large university of applied sciences. The study fields and disciplines of these three institutions encompass all major fields of higher education. The interview subjects were selected so that they represented fields and programmes that prepare students for specific occupations as well as fields with more general qualifications at the Bachelor's or Master's degree levels without specific occupational titles or professional eligibility. The interviewees represented a variety of disciplines and fields such as natural sciences, technical sciences, humanities, social sciences, theology, healthcare, educational sciences, business, and management. This ensured that the largest possible variation in terms of fields was captured in this study. The interviewees also represented different types of personnel: professors, lecturers, other teachers, managerial staff, guidance counsellors, and employment services staff.

The interviews dealt with the following themes: tasks and responsibilities of higher education in the development of generic skills; generic skills pursued in curricular planning, pedagogical processes, guidance; aims for and special pedagogic characteristics of the development of generic skills; relationships between theoretical, practical, and selfregulative knowledge in teaching; educational management, and partnerships between education and work.

\section{Methods}

The data were analysed by thematic qualitative analysis (Braun and Clarke 2006). First, the digital interview recordings were transcribed verbatim. The first and second of the three authors performed a preliminary coding, where a part of the data was subjected to datadriven classification, leading to fairly detailed categories. Next, all three authors specified the coding together and started to join the categories into larger upper categories and broader themes. The first and second authors then extended the categorisation to the whole set of data, while continuously elaborating the categories and their interrelationships. Based on the authors' joint discussion, the final upper and subcategories as well as broader themes were 
formed. As the categorisation procedure proceeded, the level of abstraction was increased so that while the preliminary categories were named by expressions taken directly from the data, the upper categories and broader themes were formed on a more conceptual basis, making up classifications on a more general level. Finally, the data were reviewed once more by considering the final shapes of the dimensions, main themes, and categories and by naming them with the titles. The analyses were data-driven in the sense that the coding and classifying were conducted inductively, based on the data, although the researchers' theoretical framework and conceptual apparatus naturally influenced their interpretations. Therefore, the process of analysis may be best characterised as a process of abductive reasoning, where the outcome is produced by the interplay of the data and the theory (Dubois and Gadde 2002).

\section{Results}

\section{Models for the development of generic skills}

Based on the interviews, we identified four models of how higher education institutes organise the development of generic skills: Specialist Model, Science-Based Renewal Model, Project-Based Integrative Model, and Model of Networked Culture. The distinctive dimensions of these models comprise the (1) structural factors, (2) pedagogy, and (3) guidance practices as a part of education.

A specific feature in the Specialist Model is that the entire task of development of generic skills is centralised to special experts, and generic skills are taught in separate courses. In the Science-Based Renewal Model, higher education is viewed to have a specific role as a creator of new knowledge, and thus as a forerunner for developing practices and ways of thinking in working life. Therefore, both generic skills and other competencies defined by present stakeholders in working life are regarded critically. The Project-Based Integrative Model highlights close integration of theory and practice in education. This integration appears typically in interactive and project-based courses. In the Model of Networked Culture, the curricular planning, educational provision, management, and operation of the higher education institutes are based on merging the different functions of the institute, namely, research, teaching, and regional development. Learning is understood to involve not only students, but also teachers, managers, work communities, and organisations. 
The models and their dimensions are summarised in Table 1. In the following section, we examine the essential contents of the main dimensions that distinguish the abovementioned models from each other and address the contents model-by-model.

\section{INSERT TABLE 1 ABOUT HERE}

\section{Structural factors}

The structural factors for the development of the generic skills identified in our data include the (1) task of HE in relation to the world of work, (2) responsibilities for workplace relations in education, and aspects of (3) management and (4) networking.

In the Specialist Model, the universities' research task is emphasised. The responsibility for workplace relations is centralised to designated personnel. The designation can be terminable and based on work rotation, or it can be agreed permanently among employer and employee at the recruitment stage, as stated by one lecturer:

I've been totally focused... from the beginning when I took this job. I promised that I'd work both in and outside the university that I'd be the person who brings the practical aspect to university teaching.

Thus, networking toward the workplace is connected to personal relations and official duties and is therefore built on representative agency. In professionally oriented study programmes that lead directly to specific occupations, the designated teaching staff cooperates with the workplace representatives, such as medical teachers with personnel in healthcare organisations. In non-professional study fields, such as humanities or social sciences, the institute's workplace connections and efforts to develop students' generic skills are enhanced by the recruitment service staff of the faculties and universities. Training for the development of generic skills has been added to study programmes; workplace representatives visit higher education institutes and students visit workplaces. Educational units also have alumni connections. Management is decentralized and based on the division of labour. Curricula and work practices are developed in broad-based working groups in departments. 
The Science-Based Renewal Model emphasises the responsibility of higher education to produce research-based knowledge, and, thus, higher education is viewed as playing an active role in creating new ways of thinking and preparing students to act as change agents in the world of work. Accordingly, in this model, the external regulation of higher education was criticised, as described by one of the interviewees:

I would not be so eager to see the kind of university that services only the needs of enterprises. My opinion is that it is not the task of the university. One of our tasks is to educate competent persons for the future; persons who have knowledge that may somehow turn the world into a better place to live.

In the Science-Based Renewal Model, workplace relations are constructed individually and collectively with the help of academic networks among persons within the same discipline. Multiprofessional networks are also constructed on an ad hoc basis. The managers of the units support the pedagogical development work by allocating resources.

In the Project-Based Integrative Model, the development of generic skills is based on opportunities for students to participate and learn in authentic learning environments, and integrate theory and practice. A typical example of this type of arrangement is project studies, the importance of which was emphasised by one professor as follows:

We have a broad course in which the students are working in groups, but they are working outside the university, for enterprises; work through which they get to test [theories] and apply knowledge of this field into practice and to practise the key working life skills. It has been nice to witness the students' wings beginning to unfold. ... This course offers us a space to stop and think about partners, and to make project plans for their needs.

Generic skills are particularly developed in work-oriented courses, which integrate theory and practice and stress on collaborative learning. The teachers of these courses are engaged in networking with the workplace and taking care of workplace relations. The management supports innovative, work-oriented teaching, seeks to remove administrative obstacles that may obstruct the activities, and allocates resources for teaching.

In the Model of Networked Culture, workplace relations form the core of the curriculum and operational strategy. The development of generic skills is embedded in all activities. The purpose is to integrate the main functions of the university (research, teaching, 
and the 'third task', societal and regional development). Thus, teaching is provided mainly in connection with broad-based projects in the world of work. The development of education and workplace relations as well as that of students' generic skills is based on collaborative planning:

We created jointly the document of pedagogical strategy. We discussed it as a group and gave comments about it. Thus, all of the actors could jointly agree on the conceptual framework of the activity. We ran pilots with the enterprises and explored how this kind of combination of research and development could support learning processes which were embedded in our mutual cooperation. Step by step, these processes became more transparent in our activities.

In this model, management is highly intentional and strategy-based and trusts in expert knowledge. Managerial activities highlight the combination of evaluation and development work. From the institutional point of view, networking is considered an important cultural factor. Educational structures, curricula, and operational practices favour networking. It is also perceived as a competency that students will need at work.

\section{Pedagogical factors}

The pedagogical factors of the development of generic skills include (1) position of generic skills in the curriculum, (2) pedagogical collaboration in the teaching of generic skills, (3) elements of expertise in learning and teaching, and (4) emphasis on learning generic skills.

In the Specialist Model, work-related matters have been placed into separate courses, as the following description by one teacher shows:

Every spring, I have had a course specifically aiming at coaching the students for working life and to give them the outsiders' thoughts about what might be worthwhile studying.

While curricular planning is collective, teaching is carried out in line with a highly specified division of labour. Education focuses on the teaching of theories. The interviewees often explained that this type of practice is the result of the lowly valued pedagogical development in the organisation. According to one lecturer,

The seamy side of the university is that if you want to develop your teaching, you don't earn credit as a scientist. The policy for recruitment - I dare say - does not value teaching at all. 
You are forced to think about your time management ... I have made a deliberate choice to invest in research and have realised that even the payroll system encourages me to do so.

Theoretical, practical, and self-regulative knowledge are treated separately, and the development of generic skills is centralised to specialists. Learning generic skills is implicitly included in the studies, but loosely expressed in the curriculum. Workplace aspects are present especially in advanced studies.

In the Science-Based Renewal Model, the central pedagogical idea is that education should offer students demanding challenges through which they can learn to solve complex problems and play an active role in new situations. A wide-ranging knowledge of theories related to the discipline, mastery of new knowledge production, and collaborative learning are at the core of the curriculum. Increasing attention has also been paid to students' skills concerning self-regulation and to their self-efficacy as learners. Learning generic skills is considered to occur as a side effect of various forms of learning activities; generic skills are not taught as separate courses. The recycling of courses among teachers, co-teaching, and interactive ways to develop pedagogy increase discussions about the aims and strategies of supporting the students in their development of generic skills.

The Project-Based Integrative Model is based on the idea that generic skills can be best learnt by working in real-life projects. In this way, theory and practice will be integrated. The projects are carried out in collaboration with the workplace, based on experimentation and learning at work, or in settings and exercises simulating work situations. The model is based on interaction, conceptualisation of practical situations, and reflection on what has been learnt. The teachers' joint planning is intensive. Connections can be created between different courses. For example, courses in communication skills may be integrated with a project course in computer science. Courses are planned to be collaborative and to highlight integration of theoretical knowledge with practical and self-regulative skills. This approach to joint planning is described well in the following interview excerpt:

We consider all of the study activities together with the teachers ... We also discuss working life skills and review what kind of skill each study activity represents ... It is also important that we can offer students various experiences. Through these experiences, students can selfassess themselves as learners, as it is very important to understand one's own learning styles in working life. 
The cohesion between different study modules is enhanced so that action-based, workoriented studies are deepened in theoretical courses, and theoretical courses are connected to work practice periods. Teachers and workplace representatives serve as content-wise and methodological supervisors of work-oriented studies. Action-based methods call for teacher resources because the student groups cannot be very large. Discussion, reflection, and argumentation play important roles in small-group activities.

In the Model of Networked Culture, the curriculum manifests the interfaces of knowledge production in various fields of higher education and the practical application of knowledge. The development of students' competencies and work orientation are seen to be important viewpoints in teaching. Expertise is shared across different fields between teaching staff, students, and workplace representatives in the networks of higher education institutes and the workplace:

Each individual member of the team aims at finding a common tune and generating quality learning in accordance with this jointly agreed framework. For example, the students eagerly engage themselves in working with the enterprises. The single teacher has no longer the sole mandate or ownership of information or knowledge.

Theory can be learnt from many sources. For example, topical workplace information reaches students in project learning. Teachers are engaged in networks with experts from the relevant fields. All teachers guide and facilitate students' learning processes. Guidance, assessment, and reflection are considered closely related and parallel processes.

The students are scaffolded to the source of information or the problem. Instead of describing the facts, the teachers send the students to examine the context and the phenomena. The essential point is that the students themselves find the core issues related to the problem.

\section{Guidance practices}

One distinguishing factor of the four models was the interrelationship between teaching, learning and guidance. This interrelationship showed up either as mutual connection between the elements or as the absence of such links within the educational activities.

In the Specialist Model, teaching and guidance can be characterised as being separate activities implemented by different members of the staff. Guidance, including the development of generic skills, is delegated to specialists, namely, personnel specialised in 
workplace issues, such as the staff responsible for recruitment services and career councelling. It is not considered to belong to teachers' tasks. As one lecturer said,

Career guidance is challenging. I try to allocate time that I get my compulsory teaching duties finished and opportunity for research. We have career guidance services and administrative staff here at our university. I prefer to advise the students to ask these relevant staff members for help.

Teachers, supervisors, and students each have clearly distinct roles. The educational approach emphasises the autonomy of students with including an idea that a student him/herself actually defines the need for guidance and searches for support services. In the curriculum, learning is composed of connected or separate modules, and students are expected to figure out and interpret possible interconnections between these blocks.

In the Science-Based Renewal Model, student-centred teaching and learning are the foci of education. Teachers want to construct a learning community in which the roles of learners and teachers are collegial. Steps toward new roles have been taken at units where students participate in genuine research projects as junior researchers. Involvement in students' career building with systematic guidance during their education is, however, viewed as unnecessary and even contradictory to the aims of higher education. Specialised guidance services are available for students at the university level.

In the Project-Based Integrative Model, the pedagogical processes emphasise collaboration. Integrative teaching that combines theoretical, practical and self-regulative knowledge takes place on a periodic basis; in other words, it is carried out in specific courses such as project studies. During these periods, teachers and students work in close collaboration. Teaching, learning, and guidance fuse with each other. Guidance is seen as a natural part of the teacher's work, including study guidance and, to some extent, career guidance tasks. Accordingly, one professor described the teachers' role as follows:

If we think about the curriculum... a student's development of expertise and his or her understanding of the subject does not begin at the stage when he/she applies for a study place. It begins from the time he/she thinks that he/she might apply for studying this subject... and we must be able to offer career guidance already at that stage. 
Cooperation between teachers is also found to be meaningful for the development of teachers' own learning and reflection. Innovative, collaborative pedagogical solutions are considered to guide the development of students' thinking as well.

In the Model of Networked Culture, teaching, guidance, and learning are merged into one whole in education. Student-centeredness is highlighted in teaching and guidance:

Redefining the student role was the core task in the pedagogical development. We need to identify which type of guidance is needed in different situations. Sometimes it is necessary to support students with the mastery of the content in order to meet the goals of the curriculum. Sometimes one has to realise that the problem is the student's motivation. Then, the focus of guidance is on increasing his/her motivation.

Teachers act as trainers and sparring partners in student groups. All staff members are committed to guiding students. Senior students serve as mentors for their juniors. In this model, guidance given to students by workplace representatives is also considered important. Further, collaborative approaches to learning are thought to promote the well-being of students and everyone involved. Learning by students, teachers, managers, and workplace representatives may even expand from the local level of the educational institution and workplace to a regional level:

The perspective of the working world is challenging. The more the students have opportunities to be engaged, the more they learn. And sometimes it is incredibly rewarding to have partnerships with enterprises that are really investing in cooperation. They also provide valuable feedback to the students during the process. They are the experts on working life, and this is a kind of expertise we cannot generate as representatives of an educational institute. Our contribution as students and trainers is related to the model of mutual cooperation. This enhances the commitment of the companies. It is a win-win situation. We generate a pilot to support them and everyone benefits.

\section{Discussion}

Our findings show that there are different approaches to the task of developing generic skills in higher education. Based on the data analysed, four different models were identified and labelled: Specialist Model, Science-Based Renewal Model, Project-based Integrative Model, and Model of Networked Culture. In the Specialist Model, workplace relations and the development of generic skills are considered separate from other teaching, as something 
belonging to designated specialists. Nonetheless, the need for generic skills and their significance is acknowledged. This model is characterised by a large variety of different and separate methodological solutions regarding the development of generic skills. In the Science-Based Renewal Model, workplace relations are based on academic networks. Persons educated in the same discipline maintain contact with each other in scientific forums. The development of generic skills is seen to be facilitated in subject learning situations in various forms of doing and participation. The Project-Based Integrative Model typically seeks to build close connections between education and work, and the learning of generic skills is linked to theoretical teaching in various pedagogical arrangements. This model is usually applied in individual courses that combine theoretical knowledge, practical competencies, and self-regulative skills. In the Model of Networked Culture, educational workplace relations and the development of generic skills are seen as involving the internal and external networks of the entire educational institution, where workplace aspects are an integral part of educational structures, management systems, and curricula.

The four models for the development of generic skills, as identified in our analysis, can be seen as different responses by higher education to the challenges posed by rapid changes in society and the job market. In the Specialist Model, the traditional institutional structures of higher education have been added to by a parallel system specialised in workplace matters. In the Model of Networked Culture, the entire educational and operational system has been reconstructed in close cooperation with corporate partners providing the educational workplace training. In this model, the development of generic skills transforms from individual students' personal projects into a joint process involving the entire education system and the workplace. This process can be described, for example, in terms of a new type of higher education 'teachership'; it is characterised by teachers working together with their colleagues and students at the interface between education and work. The processes of teaching and learning are convergent to the extent that teachers talk about the role of their own processes in relation to students' processes. In this setting, the teacher is not entering the scene with a 'theory first' approach; instead, exploration, analysis, and reflection will take place in collaboration with the students. Teachers find, however, that they are ahead of students in this quest, owing to their experience, theoretical background, and expertise.

The four models that we outlined-Specialist Model, Science-Based Renewal Model, Project-Based Integrative Model, and Model of Networked Culture-currently seem to receive differing emphases in the two sectors of Finnish higher education. While traditional 
universities deal with their workplace relations largely on the basis of the Specialist Model, Science-Based Renewal Model, and Project-Based Integrative Model, the universities of applied sciences also features the Model of Networked Culture. This is not to say, however, that this model — with all its characteristics — would be typical in this sector either. Rather, we can state that the latter model is quite rare in general.

The four models of workplace relations seem to reflect the historical development as well, in a way. Educational structures and teaching methods, which, in the Specialist Model, highlight the development of personal expertise, are, in the three other models, already shifting toward a more collaborative and community-based knowledge construction, group methodology, as well as multidisciplinary problem solving featuring discourse across different subjects. The four models can also be categorised into two basic groups on the basis of their workplace orientation. In the Specialist Model and Science-Based Renewal Model, workplace relationships are handled as education-driven activities, whereas the ProjectBased Integrative Model and Model of Networked Culture rely on collaborative and interdisciplinary approaches to the relationships between education and the world of work.

Our modelling of the workplace relations of higher education institutes can function as an analytical tool for institutes and their units or individual study programmes and can be of benefit, for instance, in reviewing their own activities from the viewpoints of structures, pedagogy, and guidance practices. The models do not necessarily appear in their purest form in practice, meaning that not all dimensions are necessarily fully consistent with a particular model. Thus, for example, it is possible that an individual course may, in terms of its internal structures, pedagogy, and guidance, be consistent with the Project-Based Integrative Model; however, with regard to the activities of the institute as a whole, the structures may match the Specialist Model more closely. Therefore, the findings may appear different depending on the target of analysis, that is, whether it is an individual course, a study programme, a department, a faculty, or the entire institute of higher education.

\section{References}

Ballantine, J., and J. McCourt Larres. 2007. Cooperative learning: a pedagogy to improve students' generic skills? Education + Training 49: 126-37.

Barnett, R. 2004. Learning for the unknown future. Higher Education Research and Development 23: 247-60.

Barrie, S. C. 2007. A conceptual framework for the teaching and learning of generic graduate attributes. Studies in Higher Education 32: 439-58. 
Bereiter, C., and M. Scardamalia. 2003. Learning to work creatively with knowledge. In Powerful learning environments: Unravelling basic components and dimensions, eds. E. de Corte, L. Verschaffel, N. Entwistle, and J. V. Merriënboer, 55-68. Amsterdam: Elsevier.

Braun, V., and V. Clarke. 2006. Using thematic analysis in psychology. Qualitative Research in Psychology 3: 77-101.

Crebert, G., M. Bates, B. Bell, C.-J. Patrick, and V. Cragnolini. 2004. Ivory tower to concrete jungle revisited. Journal of Education and Work 17: 47-70.

Dubois, A., and L.-E. Gadde. 2002. Systematic combining: an abductive approach to case research. Journal of Business Research 55: 553-60.

Dunne, E., N. Benett, and C. Carr. 2000. Skill development in higher education and employment. In Differing visions of a learning society. Research findings, ed. F. Coffield, 105-137. Bristol: Policy Press.

Education and research 2007-2012. Development plan. Ministry of Education and Culture, Finland.

Education and Research 2011-2016. Development plan. Ministry of Education and Culture, Finland.

European Qualifications Framework. 2008. http://www.nqai.ie/documents/eqfleaflet.pdf

Framework of Qualifications for the European Higher Education Area. 2005. http://www.ond.vlaanderen.be/hogeronderwijs/bologna/documents/.

Gilbert, R., J. Balatti, P. Turner, and H. Whitehouse. 2004. The generic skills debate in research higher degrees. Higher Education Research and Development 23: 375-88.

Griffiths, T., and D. Guile. 2003. A connective model of learning: the implications for work process knowledge. European Educational Research Journal 2: 56-73.

Guile, D., and T. Griffiths. 2001. Learning through work experience. Journal of Education and Work 14: 113-31.

Heikkinen, H., P. Tynjälä, and U. Kiviniemi 2011. Integrative pedagogy in practicum. In A Practicum Turn in Teacher Education, eds. M. Mattsson, T. V. Eilertsen, and D. Rorrison, 91-112. Rotterdam: Sense Publishers.

Jones, A. 2009a. Generic attributes as espoused theory: the importance of context. Higher Education 58: 175-91.

Jones, A. 2009b. Redisciplining generic attributes: the disciplinary context in focus. Studies in Higher Education 34: 85-100. 
Kallioinen, O. 2010. Defining and comparing generic competences in higher education. European Educational Research Journal 9: 56-68.

Kember, D., D. Y. P. Leung, and R. Ma. 2007. Characterizing learning environments capable of nurturing generic capabilities in higher education. Research in Higher Education 48: 609-32.

Lisbon strategy 2000-2010. An analysis and evaluation of the methods used and results achieved. Employment and social affairs. Final report. http://www.europarl.europa.eu/activities/committees/studies.do?language=EN

Murtonen, M., E. Olkinuora, P. Tynjälä, and E. Lehtinen. 2008. Do I need research skills in working life? University students' motivation and difficulties in quantitative methods courses. Higher Education 56: 599-612.

OECD. 2013. Assessment of Higher Education Learning Outcomes. AHELO. Feasibility study report. Volume 2. Data analysis and national experiences. http://www.oecd.org/education/skills-beyond-school/AHELOFSReportVolume2.pdf

Rychen, D. S. and L. H. Salganik, eds. 2003. Key competencies for successful life and wellfunctioning society. Cambridge, MA: Hogrefe \& Huber.

Santiago, R., T. Carvalho, and R. Relva. 2008. Research and the universities' image. European Journal of Education 43: 495-512.

Stenström, M.-L. 2006. Polytechnic graduates' working-life skills and expertise. In Higher education and working life. Collaborations, confrontations and challenges, eds. P. Tynjälä, J. Välimaa, and G. Boulton-Lewis, 89-102. Amsterdam: Elsevier.

Teichler, U. 2007. Does higher education matter? Lessons from a comparative graduate survey. European Journal of Education 42: 11-34.

Tynjälä, P., P. Häkkinen, and R. Hämäläinen. 2014. Tel@work. Towards integration of theory and practice. British Journal of Educational Technology. doi: DOI: $10.1111 /$ bjet.12164.

Tynjälä, P., M. Pirhonen, T. Vartiainen, and L. Helle. 2009. Educating IT project managers through project-based learning: a working-life perspective. The Communications of the Association for Information Systems. 24: 270-88.

Tynjälä, P., V. Slotte, J. Nieminen, K. Lonka, and E. Olkinuora. 2006. From university to working life: Graduates' workplace skills in practice. In Higher education and working life: Collaborations, confrontations and challenges, eds. P. Tynjälä, J. Välimaa, and G. Boulton-Lewis, 73-88. Amsterdam: Elsevier. 
Virtanen, A. and P. Tynjälä. 2013. Kohti työelämätaitoja kehittävää yliopistopedagogiikkaa - opiskelijoiden näkökulma [Towards university pedagogy enhancing generic working life skills - students’ viewpoint. In Finnish]. Yliopistopedagogiikka 20 (2): 2-10.

Virtanen, A., P. Tynjälä, and A. Eteläpelto. 2014. Factors promoting vocational students' learning at work: study on student experiences. Journal of Education and Work. 27 (1): 43-70.

Välimaa, J. 2012. The relationship between Finnish higher education and higher education research. In Higher education research in Finland, eds. S. Ahola, and D. M. Hoffman, 27-48. Jyväskylä: University of Jyväskylä. Finnish Institute for Educational Research.

\section{List of the table(s):}

Table 1. Four models for the development of generic skills 
Table 1. Four models for the development of generic skills

\begin{tabular}{|c|c|c|c|c|c|}
\hline \multicolumn{2}{|l|}{ Dimension } & \multirow{2}{*}{$\begin{array}{l}\text { Specialist Model } \\
\text { Education emphasises } \\
\text { research-based } \\
\text { approaches and } \\
\text { researcher education. } \\
\text { Connection to the } \\
\text { world of work is } \\
\text { considered important } \\
\text { on a general level. }\end{array}$} & \multirow{2}{*}{\begin{tabular}{|l|}
$\begin{array}{l}\text { Science-Based } \\
\text { Renewal Model }\end{array}$ \\
$\begin{array}{l}\text { Universities are seen as } \\
\text { "change agents" in } \\
\text { society through the } \\
\text { creation of new } \\
\text { knowledge and research- } \\
\text { based, critical new } \\
\text { solutions. Education } \\
\text { prepares students to act } \\
\text { on the research-based } \\
\text { knowledge. }\end{array}$ \\
\end{tabular}} & \multirow{2}{*}{$\begin{array}{l}\text { Project-Based } \\
\text { Integrative Model } \\
\text { Students are provided } \\
\text { with opportunities to } \\
\text { participate and learn in } \\
\text { authentic environments, } \\
\text { usually projects. }\end{array}$} & \multirow{2}{*}{$\begin{array}{l}\text { Model of } \\
\text { Networked Culture } \\
\text { Close connections } \\
\text { between education and } \\
\text { the world of work } \\
\text { driven by shared } \\
\text { values, confidence } \\
\text { between education and } \\
\text { the workplace, and } \\
\text { commitment to } \\
\text { cooperation. }\end{array}$} \\
\hline $\begin{array}{l}\text { Structural } \\
\text { factors }\end{array}$ & $\begin{array}{l}\text { Task of higher } \\
\text { education in } \\
\text { relation to the } \\
\text { world of work: }\end{array}$ & & & & \\
\hline & $\begin{array}{l}\text { Responsibilities of } \\
\text { the workplace } \\
\text { relations: }\end{array}$ & $\begin{array}{l}\text { In the hands of } \\
\text { specialists. }\end{array}$ & $\begin{array}{l}\text { Individual and collective } \\
\text { responsibility. }\end{array}$ & $\begin{array}{l}\text { Belongs to the teachers } \\
\text { of courses and projects } \\
\text { collectively. }\end{array}$ & $\begin{array}{l}\text { Embedded in structures } \\
\text { and curriculum. }\end{array}$ \\
\hline & Networking: & $\begin{array}{l}\text { Loose networking. } \\
\text { Scarce connections to } \\
\text { outside academy are } \\
\text { built on representative } \\
\text { agency, visits and } \\
\text { alumni activities. }\end{array}$ & $\begin{array}{l}\text { Academic networks, } \\
\text { which are dynamic and } \\
\text { possibly } \\
\text { multiprofessional in } \\
\text { nature. }\end{array}$ & $\begin{array}{l}\text { Networks are based on } \\
\text { personal relations. } \\
\text { Vulnerable to changes } \\
\text { in personnel. }\end{array}$ & $\begin{array}{l}\text { Networks form the } \\
\text { basis of the educational } \\
\text { structures and work } \\
\text { practices.Educational } \\
\text { structures, curriculum, } \\
\text { and work practices } \\
\text { favour networking. } \\
\text { Networking is also } \\
\text { considered a } \\
\text { competency needed at } \\
\text { the workplace. }\end{array}$ \\
\hline $\begin{array}{l}\text { Pedagogical } \\
\text { factors }\end{array}$ & $\begin{array}{l}\text { Generic skills as } \\
\text { part of the } \\
\text { curriculum: }\end{array}$ & $\begin{array}{l}\text { Generic skills are } \\
\text { taught in separate } \\
\text { courses. }\end{array}$ & $\begin{array}{l}\text { Generic skills are } \\
\text { integrated into the } \\
\text { curriculum in the various } \\
\text { forms of learning } \\
\text { activities. They are not } \\
\text { taught as separate } \\
\text { courses. }\end{array}$ & $\begin{array}{l}\text { Generic skills are learnt } \\
\text { in work-based projects } \\
\text { which integrate theory } \\
\text { and practice. }\end{array}$ & $\begin{array}{l}\text { Generic skills are } \\
\text { linked as part of } \\
\text { curricular thinking and } \\
\text { all activities. }\end{array}$ \\
\hline & $\begin{array}{l}\text { Pedagogical } \\
\text { collaboration: }\end{array}$ & $\begin{array}{l}\text { Specialist personnel for } \\
\text { work-related matters; } \\
\text { clearly defined division } \\
\text { of labour. }\end{array}$ & $\begin{array}{l}\text { Co-planning as an aim. } \\
\text { Each person contributes } \\
\text { to the programme- } \\
\text { building with his/her } \\
\text { expertise. Interaction } \\
\text { among staff is supported. } \\
\text { The students are involved } \\
\text { in collaboration. }\end{array}$ & $\begin{array}{l}\text { Co-planning of work- } \\
\text { related courses. }\end{array}$ & $\begin{array}{l}\text { Long-term joint } \\
\text { planning and } \\
\text { collaboration among } \\
\text { teachers and } \\
\text { developers. On-going } \\
\text { sharing of expertise, } \\
\text { collegial support, and } \\
\text { training. }\end{array}$ \\
\hline & $\begin{array}{l}\text { Elements of } \\
\text { expertise in } \\
\text { learning and } \\
\text { teaching: }\end{array}$ & $\begin{array}{l}\text { Emphasis on } \\
\text { theoretical learning. } \\
\text { Theoretical, practical, } \\
\text { and self-regulative } \\
\text { knowledge are treated } \\
\text { as separate. Self- } \\
\text { regulative knowledge } \\
\text { occasionally present in } \\
\text { studies. }\end{array}$ & $\begin{array}{l}\text { Emphasis on challenging, } \\
\text { theoretical, and practical } \\
\text { problem solving. } \\
\text { Wide-ranging mastery of } \\
\text { theoretical and } \\
\text { methodological } \\
\text { knowledge is seen as a } \\
\text { core of expertise. } \\
\text { Increasing attention is } \\
\text { paid to the students' self- } \\
\text { regulation and self- } \\
\text { efficacy. }\end{array}$ & $\begin{array}{l}\text { Aiming at authentic } \\
\text { learning and } \\
\text { collaborative problem } \\
\text { solving. } \\
\text { Theoretical, practical, } \\
\text { and self-regulative } \\
\text { knowledge are } \\
\text { integrated in work- } \\
\text { related projects and } \\
\text { courses. }\end{array}$ & $\begin{array}{l}\text { Joint collaborative } \\
\text { projects between } \\
\text { students, teachers, and } \\
\text { personnel in the } \\
\text { workplace change } \\
\text { thinking and } \\
\text { operational practices. } \\
\text { Theoretical, practical, } \\
\text { self-regulative, and } \\
\text { socio-cultural } \\
\text { knowledge are } \\
\text { integrated in joined } \\
\text { development projects } \\
\text { with workplaces. }\end{array}$ \\
\hline
\end{tabular}




\begin{tabular}{|c|c|c|c|c|c|}
\hline & & $\begin{array}{l}\text { construction, and } \\
\text { scientific thinking. }\end{array}$ & $\begin{array}{l}\text { applying scientific } \\
\text { knowledge; courage and } \\
\text { creativity; social skills. }\end{array}$ & & $\begin{array}{l}\text { management and } \\
\text { networking skills. }\end{array}$ \\
\hline $\begin{array}{l}\text { Guidance } \\
\text { practices }\end{array}$ & $\begin{array}{l}\text { Guidance and } \\
\text { counselling: }\end{array}$ & $\begin{array}{l}\text { Specialised counsellors } \\
\text { working at the } \\
\text { transition between } \\
\text { education and work. } \\
\text { They also give } \\
\text { guidance for personal } \\
\text { study plans. }\end{array}$ & $\begin{array}{l}\text { Guidance as part of } \\
\text { student-centred teaching } \\
\text { focusing on studying and } \\
\text { learning. For special } \\
\text { guidance needs, students } \\
\text { are advised to ask for } \\
\text { help from a specialised } \\
\text { counsellor. }\end{array}$ & $\begin{array}{l}\text { Teachers and workplace } \\
\text { representatives as } \\
\text { content-wise and } \\
\text { methodological } \\
\text { supervisors in work- } \\
\text { related courses. } \\
\text { Guidance for personal } \\
\text { study plans. }\end{array}$ & $\begin{array}{l}\text { All teachers serve as } \\
\text { guides in project } \\
\text { learning. Guidance, } \\
\text { assessment, and } \\
\text { reflection are } \\
\text { considered to be } \\
\text { closely related and } \\
\text { parallel processes. }\end{array}$ \\
\hline
\end{tabular}

